\title{
Contribution of major bacterial groups to bacterial biomass production along a salinity gradient in the South China Sea
}

\author{
Yao Zhang ${ }^{1}$, Nianzhi Jiao, ${ }^{1, *}$, Matthew T. Cottrell ${ }^{2}$, David L. Kirchman ${ }^{2}$ \\ ${ }^{1}$ State Key Laboratory for Marine Environmental Sciences, Xiamen University, 422 Siming Nan Road, \\ Xiamen 361005, PR China \\ ${ }^{2}$ College of Marine and Earth Studies, University of Delaware, 700 Pilottown Road, Lewes, Delaware 19958, USA
}

\begin{abstract}
Bacterial abundance and assimilation of ${ }^{3} \mathrm{H}$-leucine were examined using a combination of microautoradiography and fluorescent in situ hybridization (Micro-FISH) to determine the bacterioplankton community structure and estimate the contribution of major bacterial groups to total bacterial biomass production (leucine incorporation) from the Pearl River mouth to the open water area in the South China Sea. Alpha-, beta-, gamma-proteobacteria and the Cytophaga-Flavobacterium cluster differed substantially in their relative abundance and contribution to leucine assimilation along the salinity gradient. The contribution of major bacterial groups to leucine assimilation was closely associated with their relative abundance in the communities. Alpha-proteobacteria were the dominant group in the high-salinity water in terms of abundance and ${ }^{3} \mathrm{H}$-leucine assimilation, whereas beta-proteobacteria were more important in fresh water. At all stations, gamma-proteobacteria were a minor component, but the Cytophaga-Flavobacterium cluster was always a significant component in both marine and freshwater systems. The relative abundance of bacterial groups explained the variation in ${ }^{3} \mathrm{H}$-leucine assimilation by the major bacterial groups to a great extent. At the singlebacterial group level, a statistically significant correlation between abundance and leucineuptake activity was observed for beta-proteobacteria, suggesting that the relative abundance of betaproteobacteria in bacterioplankton communities was controlled by growth-related processes. In general, the numerical dominance of the major phylogenetic groups and their contribution to total bacterial biomass production varied consistently along the salinity gradient in the South China Sea.
\end{abstract}

KEY WORDS: Proteobacteria - Cytophaga-Flavobacterium - Community - Leucine assimilation · Bacterial biomass production · Microautoradiography $\cdot$ Fluorescent in situ hybridization

\section{INTRODUCTION}

Bacterial biomass and production are central factors in inferring the role of bacterioplankton in the microbial loop and carbon cycling in the ocean. Bacterial production is usually estimated from incorporation of ${ }^{3} \mathrm{H}$-thymidine or ${ }^{3} \mathrm{H}$-leucine by the whole bacterial community (Fuhrman \& Azam 1982, Kirchman et al. 1985, Simon \& Azam 1989). However, bulk measurements of bacterial production by the ${ }^{3} \mathrm{H}$-thymidine and ${ }^{3} \mathrm{H}$-leucine methods provide no information on the con- tribution of the bacterial community subcomponents. These have been examined with molecular techniques and much has been learned about bacterial biodiversity in aquatic ecosystems (Fuhrman 2002). In addition to diversity studies, techniques quantifying specific groups of bacteria are also available, such as the fluorescence in situ hybridization (FISH) approach (Delong et al. 1989, Amann et al. 1990a).

These techniques have shown that even broad phylogenetic groups vary greatly among aquatic environments. For example, alpha-proteobacteria are abun- 
dant in marine waters, whereas beta-proteobacteria and Actinobacteria are abundant in fresh waters of the salinity gradient in estuaries (Crump et al. 1999, Glöckner et al. 1999, Bouvier \& del Giorgio 2002, del Giorgio \& Bouvier 2002, Kirchman et al. 2005). The combination of FISH with microautoradiography (Micro-FISH) (Lee et al. 1999, Ouverney \& Fuhrman 1999, Cottrell \& Kirchman 2000) can be used to examine the uptake of dissolved compounds by specific bacterial groups. The contribution of major phylogenetic groups to total bacterial biomass production has been studied using Micro-FISH in only one aquatic ecosystem, the Delaware estuary (Cottrell \& Kirchman 2003, 2004).

Studies examining the bacterial abundance and assimilation of ${ }^{3} \mathrm{H}$-leucine with Micro-FISH revealed the preponderant contribution of beta-proteobacteria in fresh water and alpha-proteobacteria in salt water to thymidine and leucine assimilation of total communities (Cottrell \& Kirchman 2003). Cottrell \& Kirchman (2004) found a positive correlation between the relative abundance of beta-proteobacteria and ${ }^{3} \mathrm{H}$ thymidine-active fraction of this group in the Delaware estuary (Cottrell \& Kirchman 2004). The study of Yokokawa et al. (2004) supports these results by the dilution culture approach combined with FISH. However, it is unclear if the patterns observed in the Delaware estuary are reproducible and are present in

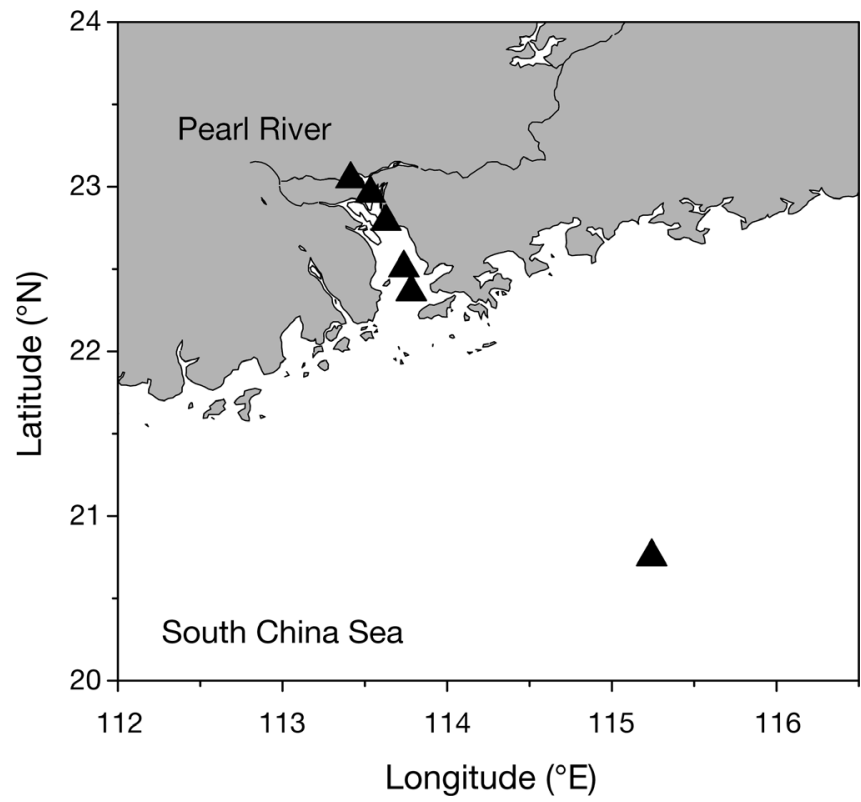

Fig. 1. Location of the 6 sampling stations $(\mathbf{\Delta})$ from the Pearl River estuary to the open water in the South China Sea. The background remote-sensing ocean image is SeaWiFSretrieved chlorophyll averaged on the corresponding investigation period and scopes downloaded from the website (http://daac.gsfc.nasa.gov/) other systems. Furthermore, little is known about bacterial community structure in subtropical systems. We need more FISH and Micro-FISH measurements in a wider range of environmental variables to better understand the dynamics of the major groups of bacteria and their roles in element cycling and bacterial biomass production.

The South China Sea is a marginal sea of the Northwest Pacific. With large amounts of fresh water and nutrient input from the Pearl River, and with oceanic water intruding into the continental shelf, the South China Sea is characterized by sharp physical and chemical gradients over a small spatial scale (Ning et al. 2004) and is thus an ideal environment for examining questions about the control of bacterioplankton communities. Here, we present data showing the change in the abundance of and the contribution to total bacterial biomass production by major bacterial groups (alpha-, beta-, gamma-protobacteria and the Cytophaga-Flavobacterium cluster) along a salinity gradient from the Pearl River estuary to the open water in the South China Sea.

\section{MATERIALS AND METHODS}

Sample collection and incubation. A $410 \mathrm{~km}$ transaction from the Pearl River estuary to the open water in the South China Sea was sampled during a winter cruise (February 2004) when phytoplankton biomass was high (Ning et al. 2004) (Fig. 1). Field experiments were conducted at 6 stations along a salinity gradient. Samples of $10 \mathrm{ml}$ taken at $1 \mathrm{~m}$ depth were immediately fixed with fresh paraformaldehyde ( $2 \%$ final concentration) and stored at $4{ }^{\circ} \mathrm{C}$ for $24 \mathrm{~h}$ before filtration onto $0.2 \mu \mathrm{m}$ pore size polycarbonate filters (Whatman). Filtered samples were stored at $-20^{\circ} \mathrm{C}$ for later analysis by FISH. Samples of $30 \mathrm{ml}$ for microautoradiography were incubated with ${ }^{3} \mathrm{H}$-leucine $(40 \mathrm{nM}$ final concentration; 30 to $60 \mathrm{Ci} \mathrm{mmol}^{-1}$, Beijing Atom Hightech) at the in situ temperatures for $1 \mathrm{~h}$. Killed controls were fixed prior to ${ }^{3} \mathrm{H}$-leucine addition with $2 \%$ paraformaldehyde. Incubations were terminated by fixation with $2 \%$ formaldehyde. Samples were fixed at $4^{\circ} \mathrm{C}$ overnight. After fixation, samples were filtered onto $0.2 \mu \mathrm{m}$ pore size white polycarbonate membrane filters, supported with $0.45 \mu \mathrm{m}$ nitrocellulose membranes (Whatman), washed with deionized water and stored at $-20^{\circ} \mathrm{C}$ until analysis.

Microautoradiography and fluorescent in situ hybridization (Micro-FISH). Samples for in situ hybridization were prepared using a modified procedure (Cottrell \& Kirchman 2000, 2004). Polycarbonate filters were cut into 12 pieces and placed with the celladherent side in contact with a $30 \mu \mathrm{l}$ drop of hybridization solution 
containing $2.5 \mathrm{ng}$ probe $\mu^{-1}$ on parafilm covering a glass slide. The relative abundance of major phylogenetic groups was determined using CY3-labled (Operon Technologies) probe Eub338 for eubacteria (Amann et al. 1990b), Alf968 for alpha-proteobacteria (Glöckner et al. 1999), Bet42a for beta-proteobacteria (Manz et al. 1992), Gam42a for gamma-proteobacteria, and CF319a for the Cytophaga-Flavobacterium cluster (Manz et al. 1996). A negative control probe was used to test for nonspecific binding (Karner \& Fuhrman 1997). Samples were hybridized for 18 to $20 \mathrm{~h}$ at $42^{\circ} \mathrm{C}$ (Cottrell \& Kirchman 2003, 2004). The hybridization solution contained $0.9 \mathrm{M} \mathrm{NaCl}, 20 \mathrm{mM}$ Tris- $\mathrm{HCl}$ (pH 7.2), $0.01 \%$ sodium dodecyl sulfate, and the concentration of formamide determined to achieve specificity for the bacterial groups targeted by the different probes (Zarda et al. 1997, Eilers et al. 2000). After hybridization, the samples were transferred to a wash solution containing $20 \mathrm{mM}$ Tris- $\mathrm{HCl}(\mathrm{pH}$ 7.2), 10 mM EDTA, $0.01 \%$ sodium dodecyl sulfate, and a concentration of $\mathrm{NaCl}$ appropriate for the probe (Zarda et al. 1997, Eilers et al. 2000) at $48^{\circ} \mathrm{C}$ for $15 \mathrm{~min}$. The sample was then rinsed with $80 \%$ EtOH and air-dried.

Before Micro-FISH, a series of exposure times, typically 1, 3 and $5 \mathrm{~d}$, was tested to determine exposure times that would yield approximately $30 \%$ of the total community with silver grains and $<3 \%$ for negative control samples. The exposure time was then used in autoradiography (Cottrell \& Kirchman 2003, 2004).

After the FISH procedure, polycarbonate filters were prepared for microautoradiography (Tabor \& Neihof 1984, Carman 1993, Cottrell \& Kirchman 2003, 2004). A glass slide was dipped into a molten $\left(43^{\circ} \mathrm{C}\right)$ solution of NTB-2 emulsion (Kodak) diluted to 1 part emulsion and 2 parts deionized water. The filters were placed with the cell adherent sides in contact with the molten emulsion. The glass slides were then placed on an icecold aluminum block for 15 min to solidify the emulsion before being transferred to light tight boxes for autoradiographic exposure that ranged from 1 to $6 \mathrm{~d}$ at $4^{\circ} \mathrm{C}$. Emulsion was developed using Dektol developer (Kodak), a deionized-water stop bath and fixer (Kodak) following the manufacturer's instructions. The slides were then rinsed in water for $10 \mathrm{~min}$, dipped into $1 \%$ glycerol for 2 min, dried overnight in a vacuum chamber with desiccant and the polycarbonate filter was peeled away from the emulsion. The samples were mounted with cover slips using a 4:1 mixture of the antifade mountants Citifluor (Ted Pella) and Vectashield (Vector Labs) with $2 \mu \mathrm{g} \mathrm{ml} \mathrm{m}^{-1}$ solution of 4',6diamidino-2-phenylindole (DAPI) (Cottrell \& Kirchman 2003, 2004).

Semi-automated microscopy and image analysis. Samples were assayed using semi-automated microscopy and image analysis of fluorescence and transmitted light images acquired with a SPOT-RT mono- chrome charge coupled device (CCD) camera (Diagnostics Instruments) mounted on an Olympus Provis AX70 microscope with a $100 \mathrm{~W}$ mercury lamp and a tungsten lamp (Cottrell \& Kirchman 2003). Cells in 10 microscopic fields were examined. Three images were acquired for each field of view using a $100 \times$ UPlanApo oil immersion objective. DAPI images were acquired using $150 \mathrm{~ms}$ exposure with a gain limit of 4 using the band-pass emission filter set 31000 (Chroma), whereas CY3 images were collected using manual exposure with filter set 41007 (Chroma). Exposure time was optimized manually to restrict background CY3 counts obtained by the negative control probe to be less than $3 \%$ of DAPI counts (Cottrell \& Kirchman 2003). Images of silver grains were collected using transmitted light illumination with automatic exposure adjusted to overexpose the image, thus eliminating objects with low optical density and capturing only objects with high optical density against a uniform white background (Cottrell \& Kirchman 2003). The image analysis was conducted with Image Pro (Media Cybernetics) to identify DAPI-stained cells, probe-positive cells and cells with silver grain as described (Cottrell \& Kirchman 2003). A program (www.ocean.udel.edu/cms/ mcottrell/\#microfish) was edited to calculate automatically the probe-positive fraction of DAPI-stained cells, the probe-positive fraction of cells with silver and the silver grains-positive fraction of probe-positive. Silver grain area was also measured with Image Pro (Media Cybernetics) to estimate the contribution of bacterial groups to leucine assimilation.

Total chlorophyll a determination. Chlorophyll was measured by the acetone extraction fluorescence method (Holm-Hansen et al. 1965) using $250 \mathrm{ml}$ of seawater samples. Since the fluorometric procedure for chlorophyll a determination can suffer interference from chlorophyll $b$ or divinyl chlorophyll $b$-containing Prochlorococcus (Goericke \& Repeta 1993), which is usually abundant in oligotrophic tropical waters, spectrophotometry was often used to calibrate the results obtained by using fluorometry.

\section{RESULTS}

Samples from 6 stations were examined by FISH and Micro-FISH, along a $410 \mathrm{~km}$ transect from the Pearl River estuary to the open water in the South China Sea (Fig. 2A). The 6 stations spanned a range of salinities from 1 to 34.5 PSU (Fig. 2A). The concentration of chlorophyll decreased rapidly with increasing salinity, and there was a small peak at the station where fresh water and sea water mixed sufficiently (Fig. 2A). Total prokaryote abundance (DAPI-stained cells) varied 4 -fold over the salinity range (Fig. 2B), and trans- 

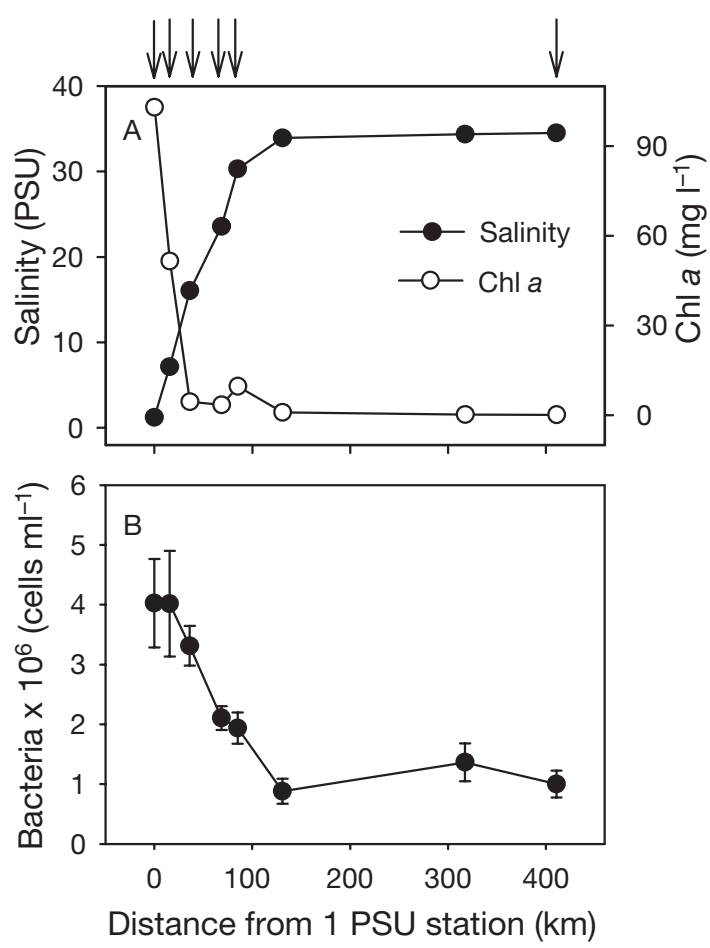

Fig. 2. Distribution of (A) salinity and chlorophyll, and (B) bacterial abundance in the South China Sea. Arrows indicate the location of stations where the assimilation of ${ }^{3} \mathrm{H}$-leucine by bacterial groups was measured using autoradiography and FISH. Error bars $= \pm \mathrm{SD}$

parency increased with increasing salinity (data not shown). The concentration of chlorophyll and total prokaryote abundance varied from 102.9 to $0.15 \mu \mathrm{g} \mathrm{l}^{-1}$ and from 4 to $1 \times 10^{6}$ cells ml $\mathrm{m}^{-1}$ (Fig. 2B), respectively, at the 6 stations sampled for Micro-FISH.

\section{Bacterial community composition}

Bacterial community structure was examined by FISH independent of the Micro-FISH analysis. On average, $67 \pm 16 \%$ of total prokaryotes (DAPI-stained cells) were detected by FISH with probes for alpha-, beta-, and gamma-proteobacteria and the CytophagaFlavobacterium cluster, whereas $58 \pm 12 \%$ of cells were detected with the general probes for bacteria (Eub338). There were remarkable differences in the spatial distribution of the different bacterial groups along the salinity gradient from the Pearl River estuary to the open water of the South China Sea. The relative abundance of alpha-proteobacteria increased with increasing salinity, whereas the reverse was observed for beta-proteobacteria (Fig. 3A). The beta-proteobacterial abundance was high in fresh water $(30 \pm 3 \%$ at
1 PSU), second only to the Cytophaga-Flavobacterium cluster, but they accounted for the smallest fraction in open water ( $5 \pm 1.5 \%$ at 34.5 PSU) (Fig. 3A). In contrast, the alpha-proteobacteria dominated the communities in high salinity water $(26 \pm 7 \%$ at 24 PSU, $29 \pm$ $7 \%$ at $30 \mathrm{PSU}$ and $31 \pm 7 \%$ at $34.5 \mathrm{PSU}$ ) and were rare in fresh water $(<10 \%$ at 1 PSU station) (Fig. 3A).

Bacterial communities at the 3 stations with the lowest salinity were dominated by the CytophagaFlavobacterium cluster, which respectively comprised $45 \pm 4,21 \pm 3$ and $24 \pm 4 \%$ of the communities at the 1, 7 and 16 PSU stations, whereas the Cytophaga-
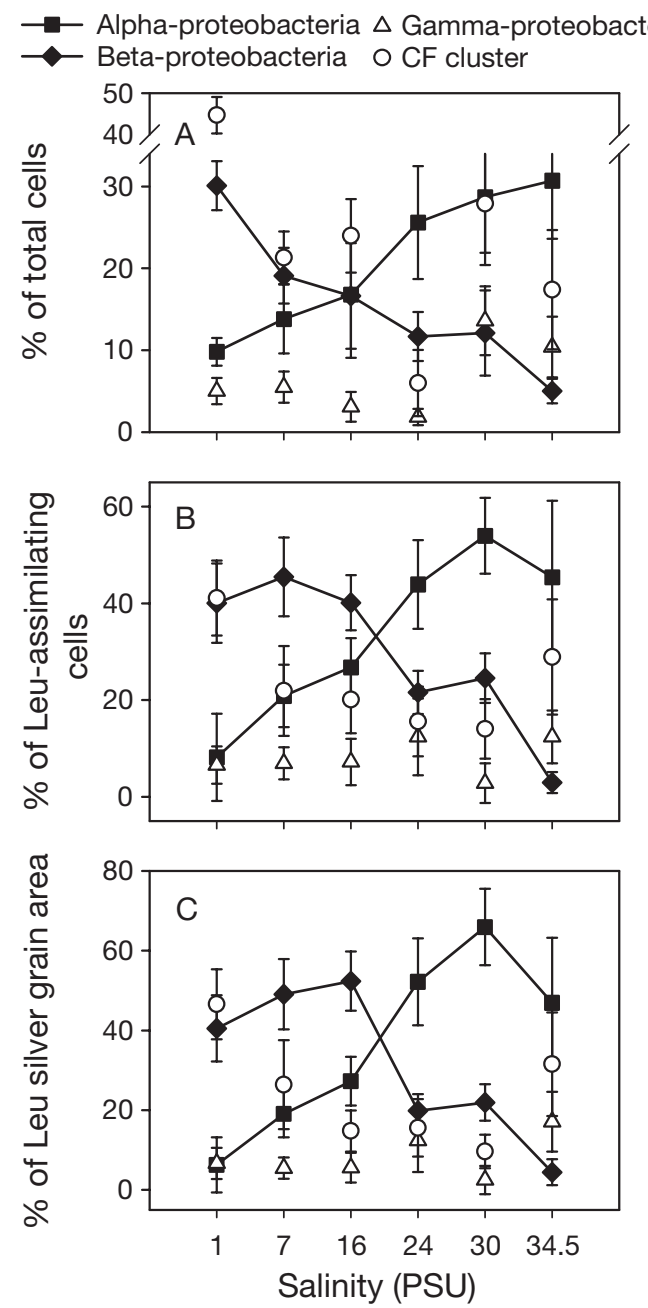

Fig. 3. Relative abundance of bacterial groups in (A) the total bacterial communities and (B) the ${ }^{3} \mathrm{H}$-leucine-assimilating populations, and (C) percentage of ${ }^{3} \mathrm{H}$-leucine silver grain cluster area associated with different bacterial groups at 6 stations. Alpha-, beta-, and gamma-proteobacterial subclasses and the Cytophaga-Flavobacterium (CF) cluster were detected with oligonucleotide probes Alf968, Bet42a, Gam42a, and CF319a, respectively. Error bars $= \pm$ SD of 10 fields of view 
Flavobacterium cluster and alpha-proteobacterial group co-dominated the community at 30 PSU stations, with each group comprising about $28 \%$. In the open water (34.5 PSU), the Cytophaga-Flavobacterium cluster was still prevalent, second only to alpha-proteobacteria (Fig. 3A). Gamma-proteobacteria were present at all stations and were always the minor member of the groups we examined, making up typically less than $14 \%$ of the prokaryotes (Fig. 3A).

\section{Bacterial groups assimilating leucine}

The contribution of the bacterial groups to total ${ }^{3} \mathrm{H}$ leucine assimilation was examined by Micro-FISH. Nearly all (94 $\pm 2 \%$ ) of the ${ }^{3} \mathrm{H}$-leucine-assimilating bacteria were detected with probes for the phylogenetic bacterial groups we examined. The largest component was alpha-proteobacteria, assimilating ${ }^{3} \mathrm{H}-$ leucine at the 3 higher salinity stations, respectively accounting for $44 \pm 9,54 \pm 8$ and $45 \pm 16 \%$ of prokaryotes assimilating ${ }^{3} \mathrm{H}$-leucine at 24,30 and 34.5 PSU stations, while they made up only $8 \pm 6,21 \pm 6$ and $27 \pm$ $6 \%$ of the total assemblages assimilating ${ }^{3} \mathrm{H}$-leucine at the 1, 7 and 16 PSU stations (Fig. 3B). In contrast, betaproteobacteria were the largest component in the total ${ }^{3} \mathrm{H}$-leucine-assimilating bacteria at 3 freshwater stations, respectively accounting for $40 \pm 8,45 \pm 8$ and $40 \pm 6 \%$, while they made up only $22 \pm 4,24 \pm 5$ and $3 \pm$ $2 \%$ of the ${ }^{3} \mathrm{H}$-leucine-assimilating bacteria at the 3 higher salinity stations (Fig. 3B). The CytophagaFlavobacterium cluster also was an important member assimilating ${ }^{3} \mathrm{H}$-leucine, and even co-dominated the assimilation of ${ }^{3} \mathrm{H}$-leucine with beta-proteobacteria at the lowest salinity station (Fig. 3B). At all 6 stations, gamma-proteobacteria were responsible for $<13 \%$ of the ${ }^{3} \mathrm{H}$-leucine-assimilating bacteria (Fig. 3B).

\section{Leucine assimilation at the single-cell level}

We also measured the size of silver grain clusters to examine the assimilation of leucine by different bacterial groups. The size of silver grain clusters varied considerably with coefficients of variation of 38 to $85 \%$ in a phylogenetic group (Table 1). Although there was substantial variation, the silver grain area data showed similar percent contribution as the data on the percent of leucine-active cells (Fig. 3C). There was a significant positive correlation between the percentage of the ${ }^{3} \mathrm{H}$-leucine-assimilating cells and the silver grain area associated with the 4 bacterial groups ( $\mathrm{r}=0.98$, $\mathrm{n}=24, \mathrm{p}<0.01)$. Alpha-proteobacteria accounted for the largest fraction of the ${ }^{3} \mathrm{H}$-leucine silver grain area at the 3 higher salinity stations where they were domi- nant (Fig. 3C). In contrast, beta-proteobacteria had large silver grain areas at the 3 freshwater stations, whereas the areas were small at the 3 higher salinity stations (Fig. 3C). The Cytophaga-Flavobacterium cluster accounted for the largest fraction of the ${ }^{3} \mathrm{H}$ leucine silver grain area (47 $\pm 9 \%$ ) at the 1 PSU station, where this bacterial group co-dominated the ${ }^{3} \mathrm{H}$ leucine-assimilating bacteria with beta-proteobacteria $(\sim 40 \%)$. At all 6 stations, gamma-proteobacteria appeared to be minor contributors to ${ }^{3} \mathrm{H}$-leucine assimilation, responsible for $<17 \%$ of the silver grain area (Fig. 3C).

\section{Relationship between relative abundance of major bacterial groups and their contribution to total ${ }^{3}$ H-leucine assimilation}

We observed significant positive correlations between the abundance of the various groups and their contribution to total leucine assimilation in terms of the percentage of total cells with silver grains $(\mathrm{r}=0.90, \mathrm{p}<$ 0.01) (Fig. 4A) and percentage of total silver grains ( $\mathrm{r}=$ 0.87, $\mathrm{p}<0.05$ ) (Fig. 4B). These correlations suggested that abundant bacterial groups contributed more to

Table 1. Size of silver grain clusters associated with alpha-, beta-, and gamma-proteobacteria and the CytophagaFlavobacterium (CF) cluster assimilating ${ }^{3} \mathrm{H}$-leucine at 6 stations. N: number of bacteria examined for each group

\begin{tabular}{|c|c|c|c|c|c|}
\hline \multirow{2}{*}{$\begin{array}{l}\text { Salinity } \\
\text { (PSU) }\end{array}$} & \multirow[t]{2}{*}{ Statistics } & \multicolumn{3}{|c|}{ Proteobacteria } & \multirow{2}{*}{$\begin{array}{c}\mathrm{CF} \\
\text { cluster }\end{array}$} \\
\hline & & Alpha & Beta & Gamma & \\
\hline \multirow[t]{4}{*}{1} & Mean $\left(\mu m^{2}\right)$ & 1.93 & 2.49 & 2.49 & 2.79 \\
\hline & Median $\left(\mu m^{2}\right)$ & 1.76 & 2.17 & 2.03 & 2.45 \\
\hline & $\mathrm{SD}$ & 0.81 & 1.41 & 1.61 & 1.28 \\
\hline & $\mathrm{N}$ & 26 & 40 & 26 & 36 \\
\hline \multirow[t]{4}{*}{7} & Mean $\left(\mu m^{2}\right)$ & 2.24 & 2.57 & 1.86 & 2.93 \\
\hline & Median $\left(\mu m^{2}\right)$ & 1.81 & 2.03 & 1.54 & 2.47 \\
\hline & SD & 1.22 & 1.70 & 1.05 & 1.73 \\
\hline & $\mathrm{N}$ & 81 & 112 & 73 & 71 \\
\hline \multirow[t]{4}{*}{16} & Mean $\left(\mu m^{2}\right)$ & 2.53 & 3.21 & 1.89 & 1.78 \\
\hline & Median $\left(\mu \mathrm{m}^{2}\right)$ & 2.20 & 2.53 & 1.59 & 1.62 \\
\hline & $\mathrm{SD}$ & 1.52 & 2.24 & 1.06 & 0.73 \\
\hline & $\mathrm{N}$ & 118 & 119 & 61 & 58 \\
\hline \multirow[t]{4}{*}{24} & Mean $\left(\mu m^{2}\right)$ & 3.08 & 2.44 & 2.59 & 2.62 \\
\hline & Median $\left(\mu m^{2}\right)$ & 2.47 & 2.06 & 2.09 & 2.36 \\
\hline & $\mathrm{SD}$ & 2.08 & 1.47 & 1.64 & 1.47 \\
\hline & $\mathrm{N}$ & 105 & 106 & 43 & 85 \\
\hline \multirow[t]{4}{*}{30} & Mean $\left(\mu m^{2}\right)$ & 4.14 & 3.04 & 2.87 & 2.34 \\
\hline & Median $\left(\mu m^{2}\right)$ & 3.32 & 2.80 & 2.58 & 2.20 \\
\hline & SD & 3.51 & 1.40 & 1.71 & 1.16 \\
\hline & $\mathrm{N}$ & 100 & 80 & 29 & 53 \\
\hline \multirow[t]{4}{*}{34.5} & Mean $\left(\mu m^{2}\right)$ & 1.79 & 2.62 & 2.41 & 1.89 \\
\hline & Median $\left(\mu m^{2}\right)$ & 1.48 & 2.03 & 1.98 & 1.48 \\
\hline & SD & 0.95 & 1.91 & 1.58 & 1.06 \\
\hline & $\mathrm{N}$ & 126 & 117 & 65 & 94 \\
\hline
\end{tabular}


- Alpha-proteobacteria $\Delta$ Gamma-proteobacteria - Beta-proteobacteria O CF cluster
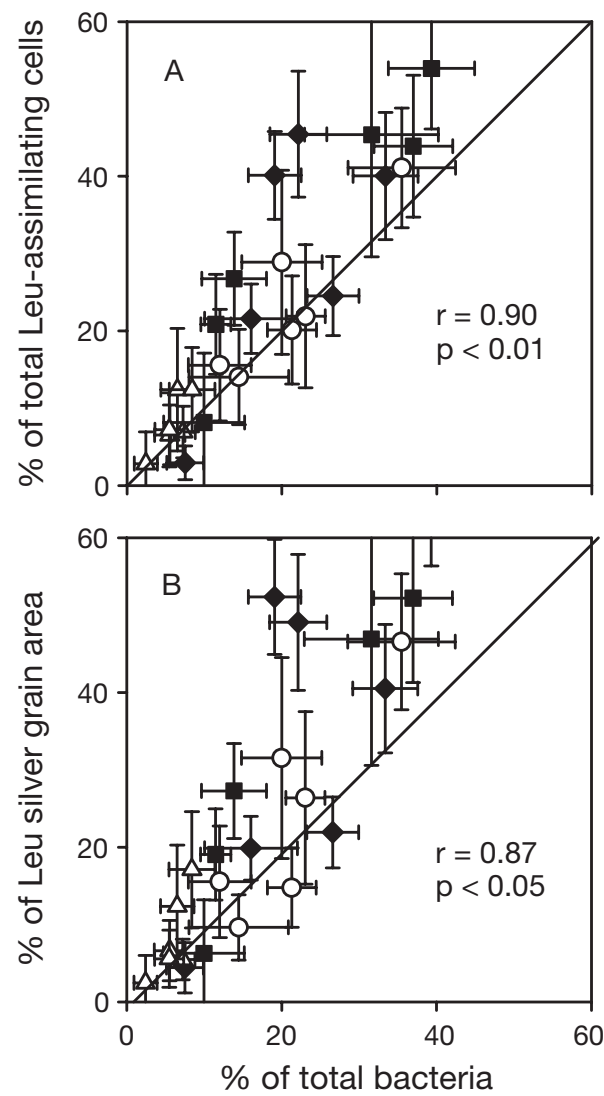

Fig. 4. Relationship between abundance of various groups and their contribution to total leucine assimilation in terms of the (A) percentage of total cells with silver grains and (B) percentage of total silver grains. Alpha-, beta-, and gammaproteobacterial subclasses and the Cytophaga-Flavobacterium (CF) cluster were detected with oligonucleotide probes Alf968, Bet42a, Gam42a, and CF319a, respectively. Error bars $= \pm \mathrm{SD}$ of 10 fields of view. Diagonal line indicates a 1:1 relationship

${ }^{3} \mathrm{H}$-leucine assimilation than minor groups. For example, alpha-proteobacteria were the dominant component in both abundance and ${ }^{3} \mathrm{H}$-leucine-assimilation at the 24, 30 and 34.5 PSU stations, but not at the 1, 7 and 16 PSU stations (Fig. 4). Likewise, beta-proteobacterial fractions of both total bacteria and ${ }^{3} \mathrm{H}$-leucine assimilation were much higher at the freshwater stations than at the high salinity stations (Fig. 4).

However, abundance was not an adequate predictor of a bacterial group's contribution to total bacterial production. The slope of the linear regression was $>1$ (Fig. 4), indicating that the contribution of predominant bacterial groups to total ${ }^{3} \mathrm{H}$-leucine assimilation was greater than what would be predicted solely from their relative abundance. For example, ${ }^{3} \mathrm{H}$-leucine assimilation by alpha-preteobacteria (44 to $66 \%$, based on relative number of ${ }^{3} \mathrm{H}$-leucine active cells and silver grain area) was greater than that estimated from their relative abundance (32 to $39 \%$ ) at the high salinity stations (Fig. 4). Beta-proteobacteria comprised a large fraction of the total community (19 to $33 \%$ ) and a disproportionately large fraction of the ${ }^{3} \mathrm{H}$-leucine assimilation (40 to $52 \%$ ) at the low salinity stations (Fig. 4).

\section{Fraction of bacterial groups assimilating leucine}

We also calculated the ${ }^{3} \mathrm{H}$-leucine-active fraction of bacterial groups to estimate variations in cell activity at group level. This differs from the data reported above on the fraction of leucine-assimilating bacteria belonging to a phylogenetic group. For example, gammaproteobacteria accounted for only $7 \%$ of the cells assimilating leucine, but $31 \%$ of gamma-proteobacteria took up leucine. The ${ }^{3} \mathrm{H}$-leucine-active fraction of a single phylogenetic group varied substantially for alpha-, beta- and gamma-proteobacteria, and the Cytophaga-Flavobacterium cluster (10 to $47 \%$ ). There was no consistent pattern along the salinity gradient (Table 1).

\section{Relationship between relative abundance and leucine-active fraction of major bacterial groups}

The relationship between relative abundance and the leucine-active fraction of the major bacterial groups was examined to test whether bacterial growth-related processes control the size of phylogenetic groups and, consequently, regulate community structure. There was a significant positive correlation between the leucine-active fraction of beta-proteobacteria and beta-proteobacterial relative abundance in total communities $(\mathrm{r}=0.88 ; \mathrm{p}<0.05)$ (Fig. 5B), suggest-

Table 2. Percentage of ${ }^{3} \mathrm{H}$-leucine active bacteria in alpha-, beta-, gamma-proteobacteria and the Cytophaga-Flavobacterium (CF) cluster bacteria in the South China Sea. SD (in parentheses) is based on 10 microscopic fields of view

\begin{tabular}{|c|c|c|c|c|}
\hline \multirow{2}{*}{$\begin{array}{l}\text { Salinity } \\
\text { (PSU) }\end{array}$} & \multirow[b]{2}{*}{$\begin{array}{l}\text { Alpha- } \\
\text { proteo- } \\
\text { bacteria }\end{array}$} & \multicolumn{2}{|c|}{$\%$ assimilating ${ }^{3} \mathrm{H}$-leucine } & \multirow[b]{2}{*}{$\begin{array}{c}\mathrm{CF} \\
\text { cluster }\end{array}$} \\
\hline & & $\begin{array}{c}\text { Beta- } \\
\text { proteo- } \\
\text { bacteria }\end{array}$ & $\begin{array}{c}\text { Gamma- } \\
\text { proteo- } \\
\text { bacteria }\end{array}$ & \\
\hline 1 & 18 (19) & $32(7)$ & $31(16)$ & $32(13)$ \\
\hline 7 & $20(7)$ & $24(5)$ & $12(6)$ & $11(3)$ \\
\hline 16 & 34 (12) & 29 (9) & 20 (11) & $14(3)$ \\
\hline 24 & $26(15)$ & $13(10)$ & $25(18)$ & $16(11)$ \\
\hline 30 & $47(6)$ & $29(21)$ & $26(36)$ & 24 (9) \\
\hline 34.5 & $25(6)$ & $10(8)$ & 31 (15) & $30(11)$ \\
\hline
\end{tabular}




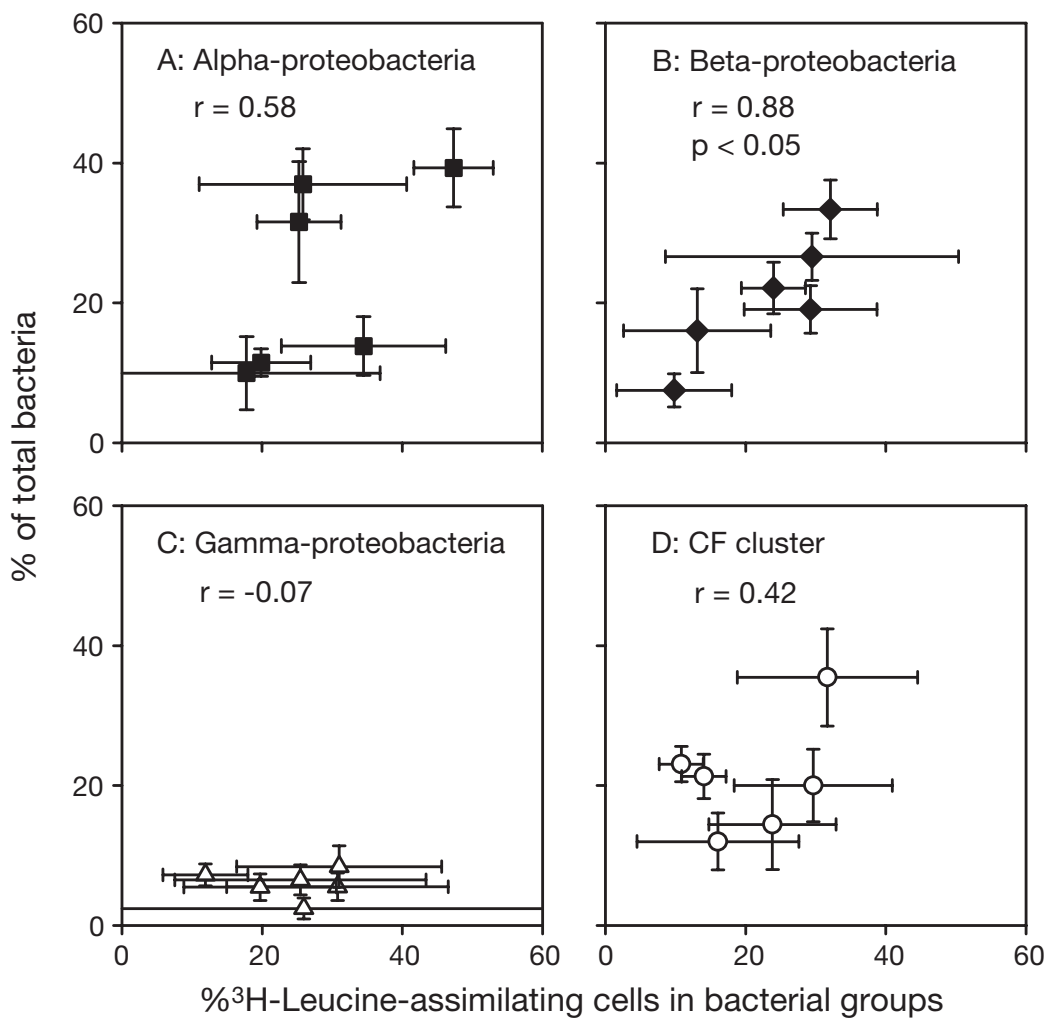

Fig. 5. Correlation between the relative abundance of (A) alpha-proteobacteria, (B) beta-proteobacteria, (C) gamma-proteobacteria, and (D) CytophagaFlavobacterium $(\mathrm{CF})$ cluster, and the percentage of ${ }^{3} \mathrm{H}$-leucine active bacteria in the these groups in the South China Sea in February 2004. Relationship for $\beta$-proteobacteria showed the only significant correlation. Error bars $= \pm \mathrm{SD}$ of 10 fields of view

ing that beta-proteobacteria along the salinity gradient were controlled by growth. The correlation between the relative abundance and leucine assimilation for alpha-proteobacteria was not as high $(\mathrm{r}=0.58)$ as for beta-proteobacteria (Fig. 5A), and it was insignificant for gamma-proteobacteria and the CytophagaFlavobacterium cluster (Fig. 5C,D).

\section{DISCUSSION}

One aim of this study was to examine the community composition and possible contribution of the major groups of aquatic bacteria to total bacterial biomass production in a subtropical coastal system, the South China Sea. The dominance of beta-proteobacteria in fresh water and alpha-proteobacteria in salt water has been demonstrated previously in estuarine ecosystems (Crump et al. 1999, Bouvier \& del Giorgio 2002, Kirchman et al. 2005). The results from the present study confirmed some but not all of the basic patterns previously reported. We also analyzed relationships among abundance, activity and contribution to total bacterial production of the major bacterial groups found in aquatic systems.

Alpha-proteobacteria appear to be adapted to low concentrations of dissolved organic substrates (Eiler et al. 2003, Pinhassi \& Berman 2003) and are widely distributed in marine environments (Giovannoni \& Rappé 2000). The significant positive correlation between the relative abundance of alpha-proteobacteria and salinity that we observed $(r=0.99, p<0.01)$ implies that alpha-proteobacterial abundance could be explained by the factors which co-vary with salinity. We hypothesized that oligotrophic marine genera are responsible for a substantial proportion of the alpha-proteobacteria in the study area, especially in the pelagic open sea. Beta-proteobacteria are usually most abundant in fresh waters of estuaries (Crump et al. 1999, Bouvier \& del Giorgio 2002, del Giorgio \& Bouvier 2002, Kirchman et al. 2005), and this was duly observed in the present study. Furthermore, the highly significant correlation between the relative abundance and the ${ }^{3} \mathrm{H}$ leucine-active fraction of beta-proteobacteria here $(r=0.88, p<0.05)$

(Fig. 5B) suggests a link between beta-proteobacterial abundance and its metabolic activity. This observation is consistent with a previous study showing that the abundance of beta-proteobacteria is related to allochthonous input of organic carbon in lakes (Langenheder et al. 2004). A third bacterial group, the Cytophaga-Flavobacterium cluster, is usually abundant in both marine and freshwater environments (Kirchman 2002). They are often observed to be attached to organic particles (Delong et al. 1993, Rath et al. 1998) and are abundant in the turbid estuaries (Crump et al. 1999). In this study, the CytophagaFlavobacterium cluster was the dominant group in the entire estuary and the highest abundance was observed at the freshwater station.

The results of this study indicate that the estimated contribution of bacterial groups to total bacterial biomass production based on active bacterial abundance and silver grain area was closely associated with their relative abundance in microbial communities (Figs. 3 \& 4). Alpha-proteobacteria dominated the total community and the ${ }^{3} \mathrm{H}$-leucine-active population in salt water, where the beta-proteobacterial group was a minor 
member. In contrast, beta-proteobacteria were much more important in fresh water of the estuary in terms of abundance and ${ }^{3} \mathrm{H}$-leucine assimilation than alphaproteobacteria. The positive relationships between the relative abundance of bacterial groups and their contribution to leucine assimilation of total communities verified that bacterial abundance can explain bacterial production to a great extent (Cole et al. 1988), and also suggested that bacterial abundance and production were controlled by some of the same factors, such as resource availability and bacterial activity (Ducklow 2000). Bacterial abundance could also be limited by removal processes, such as bacteriovory and viral lysis (Ducklow 2000). Analysis of silver grain area indicated that cellular growth rate varied substantially within a phylogenetic group, based on the assumption that a larger silver grain cluster area indicates higher singlecell activity (Rogers 1979). The estimated contribution of a group to bacterial production based on silver grain area agreed with that based on abundance.

To examine whether the ${ }^{3} \mathrm{H}$-leucine incorporation by the major bacterial group can explain the variation in their abundance along the salinity gradient, we plotted the leucine-active fraction for each group versus their relative abundance. The significant positive correlation was observed only for beta-proteobacteria $(\mathrm{r}=$ 0.88; p < 0.05) (Fig. 5B), suggesting that the decline in the relative abundance of beta-proteobacteria along the salinity gradient was because of lower growth in high salinity water. Consistent with our data, Cottrell \& Kirchman (2004) also found a positive correlation between the thymidine-active fraction of cells and the relative abundance for beta-proteobacteria in the Delaware estuary, although not for the leucine-active fraction. These significant correlations suggest that growth-related processes exert a stronger effect than removal processes on beta-proteobacteria, such as competition for organic carbon (Kirchman et al. 2000) and inorganic nutrients (Cotner et al. 1997), or inhibition of bacterial growth by factors such as salinity (del Giorgio \& Bouvier 2002). Even though the positive correlation for alpha-proteobacteria seems substantial in some instances (Fig. 5A), this association was not statistically significant. Cottrell \& Kirchman (2004) observed much smaller, insignificant correlation coefficients between relative abundance and thymidine and leucine uptake by alpha-proteobacteria.

We observed that the relative abundance of gammaproteobacteria was always low regardless of leucine assimilation (Fig. 5C), indicating that additional factors beyond growth could be important in controlling their abundance. These factors include bacterial mortality due to viral lysis (Fuhrman \& Suttle 1993, Wommack \& Colwell 2000) and protozoan grazing (Strom 2000). Also, the high relative abundance of the Cytophaga-
Flavobacterium cluster did not match their low leucine uptake at the 7 and 16 PSU stations (Fig. 5D), suggesting that the high abundance of the CytophagaFlavobacterium cluster may not be the result of high in situ growth. Cottrell \& Kirchman (2004) found similar results during their study of the CytophagaFlavobacterium cluster in the Delaware estuary.

The data presented here indicated that proteobacteria and the Cytophaga-Flavobacterium cluster account for the majority of the heterotrophic bacterial abundance and biomass production in the study area. The Micro-FISH data provided important clues about the abundance and bacterial production of major phylogenetic bacterial groups along the salinity gradient in this subtropical coastal system. It is probably necessary to examine finer phylogenetic levels since the proteobacterial groups and the Cytophaga-Flavobacterium cluster examined here are phylogenetically diverse. However, the large changes along the salinity gradient at the broad phylogenetic levels we examined provided invaluable information that will be essential for understanding the dynamics of the major groups of bacteria and their roles in biogeochemical processes.

Acknowledgements. We thank Hila Elifantz for teaching Y.Z. Micro-FISH and M. H. Dai for the sampling opportunity and salinity data. This research was supported by the projects NSFC40232021, 40576063, MOST2003DF000040, 2001CB409700 and MOE 40406023. M.T.C. and D.L.K. were supported by a DOE-BIOMP grant.

\section{LITERATURE CITED}

Amann RI, Krumholz L, Stahl DA (1990a) Fluorescentoligonucleotide probing of whole cells for determinative, phylogenetic, and environmental studies in microbiololgy. J Bacteriol 172:762-770

Amann RI, Binder BJ, Olson RJ, Chisholm SW, Devereux R, Stahl DA (1990b) Combination of 16S ribosomal-RNAtargeted oligonucleotide probes with flow-cytometry for analyzing mixed microbial populations. Appl Environ Microbiol 56:1919-1925

Bouvier TC, del Giorgio PA (2002) Compositional changes in free-living bacterial communities along a salinity gradient in two temperate estuaries. Limnol Oceanogr 47:453-470

Carman KR (1993) Microautoradiographic detection of microbial activity. In: Kemp PF, Sherr BF, Sherr EB, Cole JJ (eds) Handbook of methods in aquatic microbial ecology. Lewis Publishers, Boca Raton, FL, p 397-404

Cole JJ, Findlay S, Pace ML (1988) Bacterial production in fresh and saltwater ecosystems: a cross-system overview. Mar Ecol Prog Ser 43:1-10

Cotner JB, Ammerman JW, Peele ER, Bentzen E (1997) Phosphorus-limited bacterioplankton growth in the Sargasso Sea. Aquat Microb Ecol 13:141-149

Cottrell MT, Kirchman DL (2000) Natural assemblages of marine proteobacteria and members of the Cytophagaflavobacter cluster consuming low- and high-molecularweight dissolved organic matter. Appl Environ Microbiol 66:1692-1697 
Cottrell MT, Kirchman DL (2003) Contribution of major bacterial groups to bacterial biomass production (thymidine and leucine incorporation) in the Delaware estuary. Limnol Oceanogr 48:168-178

Cottrell MT, Kirchman DL (2004) Single-cell analysis of bacterial growth, cell size, and community structure in the Delaware estuary. Aquat Microb Ecol 34:139-149

Crump BC, Armbrust EV, Baross JA (1999) Phylogenetic analysis of particle-attached and free-living bacterial communities in the Columbia River, its estuary, and the adjacent coastal ocean. Appl Environ Microbiol 65:3192-3204

del Giorgio PA, Bouvier TC (2002) Linking the physiologic and phylogenetic successions in free-living bacterial communities along an estuarine salinity gradient. Limnol Oceanogr 47:471-486

Delong EF, Wickham GS, Pace NR (1989) Phylogenetic strains: ribosomal RNA-based probes for the identification of single cells. Science 243:1360-1363

Delong EF, Franks DG, Alldredge AL (1993) Phylogenetic diversity of aggregate-attached vs. free-living bacterial communities along an estuarine salinity gradient. Limnol Oceanogr 47:471-486

Ducklow H (2000) Bacterial production and biomass in the oceans. In: Kirchman DL Microbial ecology of the oceans. Wiley-Liss Publishers, New York, p 85-120

Eiler A, Langenheder S, Bertilsson S, Tranvik LJ (2003) Heterotrophic bacterial growth efficiency and community structure at different natural organic carbon concentrations. Appl Environ Microbiol 69:3701-3709

Eilers H, Pernthaler J, Glöckner FO, Amann R (2000) Culturability and in situ abundance of pelagic bacteria from the North Sea. Appl Environ Microbiol 66:3044-3051

Fuhrman JA (2002) Community structure and function in prokaryotic marine plankton. Antonie Leeuwenhoek 81: 521-527

Fuhrman JA, Azam F (1982) Thymidine incorporation as a measure of heterotrophic bacteriaoplankton production in marine surface waters - evaluation and field results. Mar Biol 66:109-120

Fuhrman JA, Suttle CA (1993) Viruses in marine planktonic systems. Oceanography 6:50-62

Giovannoni S, Rappé M (2000) Evolution, diversity, and molecular ecology of marine prokaryotes. In: Kirchman DL (ed) Microbial ecology of the oceans. Wiley-Liss Publishers, New York, p 47-84

Glöckner FO, Fuchs BM, Amann R (1999) Bacterioplankton compositions of lakes and oceans: a first comparison based on fluorescence in situ hybridization. Appl Environ Microbiol 65:3721-3726

Goericke R, Repeta DJ (1993) Chlorophylls $a$ and $b$ and divinyl chlorophylls $a$ and $b$ in the open subtropical North Atlantic Ocean. Mar Ecol Prog Ser 101:307-313

Holm-Hansen O, Lorenzen CJ, Holms RW, Strickland JDH (1965) Fluorometric determination of chlorophyll. J Cons Perm Int Explor Mer 30:3-15

Karner M, Fuhrman JA (1997) Determination of active marine bacterioplankton: a comparison of universal 16S rRNA probes, autoradiography, and nucleoid staining. Appl Environ Microbiol 63:1208-1213

Kirchman DL (2002) The ecology of Cytophaga-Flavobacteria in aquatic environments. FEMS Microbiol Ecol 39:91-100

Kirchman DL, K'ness E, Hodson R (1985) Leucine incorporation and its potential as a measure of protein synthesis by

Editorial responsibility: Jed Fuhrman,

Los Angeles, California, USA bacteria in natural waters. Appl Environ Microbiol 49: 599-607

Kirchman DL, Dittel AI, Malmstrom RR, Cottrell MT (2005) Biogeography of major bacterial groups in the Delaware estuary. Limnol Oceanogr 50:1697-1706

Kirchman DL, Meon B, Cottrell MT, Hutchins DA, Weeks D, Bruland KW (2000) Carbon versus iron limitation of bacterial growth in the California upwelling regime. Limnol Oceanogr 45:1681-1688

Langenheder S, Kisand V, Lindström ES, Wikner J, Tranvik LJ (2004) Growth dynamics within bacterial communities in riverine and estuarine batch cultures. Aquat Microb Ecol 37:137-148

Lee N, Nielsen PH, Andreasen KH, Juretschko S, Nielsen JL, Schleifer KH, Wagner M (1999) Combination of fluorescent in situ hybridization and microautoradiography-a new tool for structure-function analyses in microbial ecology. Appl Environ Microbiol 65:1289-1297

Manz W, Amann R, Ludwig W, Wagner M, Schleifer KH (1992) Phylogenetic oligodeoxynucleotide probes for the major subclasses of proteobacteria-problems and solutions. Syst Appl Microbiol 15:593-600

Manz W, Amann R, Ludwig W, Vancanneyt M, Schleifer KH (1996) Application of a suite of 16S rRNA-specific oligonucleotide probes designed to investigate bacteria of the phylum Cytophaga-Flavobacter-Bacteroides in the natural environment. Microbiology 142:1097-1106

Ning X, Chai F, Xue H, Cai Y, Liu C, Shi J (2004) Physical-biological oceanographic coupling influencing phytoplankton and primary production in the South China Sea. J Geophys Res 109: C10005, doi: 10.1029/2004JC002365

Ouverney CC, Fuhrman JA (1999) Combined microautoradiography-16S rRNA probe technique for determination of radioisotope uptake by specific microbial cell types in situ. Appl Environ Microbiol 65:1746-1752

Pinhassi J, Berman T (2003) Differential growth response of colony-forming alpha- and gamma-Proteobacteria in dilution cultures and nutrient addition experiments from Lake Kinneret (Israel), the Eastern Mediterranean Sea, and the Gulf of Eilat. Appl Environ Microbiol 69:199-211

Rath J, Wu KY, Herndl GJ, Delong EF (1998) High phylogenetic diversity in a marine-snow-associated bacterial assemblage. Aquat Microb Ecol 14:261-269

Rogers AW (1979) Techniques of autoradiography, 3rd edn. Elsevier, Amsterdam

Simon M, Azam F (1989) Protein-content and protein-synthesis rates of planktonic marine-bacteria. Mar Ecol Prog Ser 51:201-213

Strom SL (2000) Bacterivory: interactions between bacteria and their grazers. In: Kirchman DL (ed) Microbial ecology of the oceans. Wiley-Liss, New York, p 351-386

Tabor PS, Neihof RA (1984) Direct determination of activities for microorganisms of Chesapeake Bay populations. Appl Environ Microbiol 48:1012-1019

Wommack KE, Colwell RR (2000) Virioplankton: viruses in aquatic ecosystems. Microbiol Mol Biol Rev 64:69-114

Yokokawa T, Nagata T, Cottrell MT, Kirchman DL (2004) Growth rate of the major phylogenetic bacterial groups in the Delaware estuary. Limnol Oceanogr 49:1620-1629

Zarda B, Hahn D, Chatzinotas A, Schonhuber W, Neef A, Amann RI, Zeyer J (1997) Analysis of bacterial community structure in bulk soil by in situ hybridization. Arch Microbiol 168:185-192

Submitted: October 12, 2005; Accepted: May 31, 2006

Proofs received from author(s): July 12, 2006 